Community: Volume 4, Nomor 2, Oktober 2018

ISSN: 2477-5746 e-ISSN: 2502-0544

\title{
Peran Perguruan Tinggi dalam Membangun Budaya Keterbukaan Informasi Publik ${ }^{1}$
}

\author{
Afrizal Tjoetra \\ Program Studi Sosiologi, FISIP, Universitas Teuku Umar \\ Email : afrizaltjoetra@utu.ac.id
}

\begin{abstract}
Abstrak
Tujuan penelitian ini untuk mengetahui kesiapan Perguruan Tinggi dalam melaksanakan Undang Undang Keterbukaan Informasi Publik dan peran yang dapat dilakukan oleh Perguruan Tinggi untuk membangun budaya keterbukaan informasi publik. Penelitian ini menggunakan metode kualitatif melalui kajian literatur. Dokumen utama yang dijadikan rujukan adalah buku, undang-undang, peraturan Komisi Informasi, serta laporan evaluasi yang dilakukan Komisi Informasi Pusat dan Komisi Informasi Aceh. Berdasarkan hasil penelitian diketahui bahwa kesiapan Perguruan Tinggi dalam melaksanakan Undang Undang Keterbukaan Informasi Publik masih belum sesuai ketentuan. Masih terdapat sejumlah tantangan yang harus dikelola bersama secara internal maupun dukungan komponen lainnya. Berikutnya, peran yang dapat dilakukan Perguruan Tinggi untuk membangun budaya keterbukaan informasi publik dapat dilaksanakan melalui 3 hal, yaitu sebagai "lokomotif" dalam melaksanakan Undang Undang Keterbukaan Informasi Publik; sebagai "fasilitator" dalam membangun masyarakat sadar informasi; dan sebagai "motivator" agar masyarakat dan badan publik lainnya dapat memanfaatkan penyediaan informasi publik untuk pengembangan ilmu pengetahuan dan mencerdaskan kehdupan bangsa.
\end{abstract}

Kata kunci: Peran, Perguruan Tinggi, keterbukaan informasi publik, budaya.

Abstract

The purpose of this study is to determine the readiness of universities in implementing the Public Information Disclosure Act and the role that can be taken by universities to build a culture of public information disclosure. This study uses qualitative methods through literature review. The main documents referred to are books, laws, Information Commission regulations, as well as evaluation reports conducted by the Central Information Commission and the Aceh Information Commissio. Based on the results of the study it is known that the readiness of universities in implementing the Public Information Disclosure Act is still not in accordance with the provisions. There are still a number of challenges that must be managed jointly internally as well as the support of other components. Next, the role that universities can play in building a culture of public information disclosure can be carried out through 3 things, namely as a "locomotive" in implementing the Public Information Disclosure Act; as a "facilitator" in building information-aware communities; and as a "motivator" so that the public and other public bodies can make use of the provision of public information for the development of knowledge and educate the nation's life.

Keywords: Roles, universities, public information disclosure, culture.

\footnotetext{
${ }^{1}$ Tulisan ini sebelumnya disampaikan pada Kuliah Umum yang dilaksanakan Prodi Ekonomi, FKIP, Universitas Syiah Kuala, Banda Aceh, 4 April 2018.
} 


\section{PENDAHULUAN}

Setiap orang mempunyai hak untuk berkomunikasi dan memperoleh informasi publik untuk mengembangkan pribadi dan lingkungan sosialnya, serta berhak untuk mencari, memperoleh, memiliki, dan menyimpan informasi dengan menggunakan segala jenis saluran yang tersedia ${ }^{2}$. Berikutnya, guna memastikan berlangsungnya jaminan terhadap pemenuhan hak dimaksud, pada 30 April 2008 lalu, Pemerintah Republik Indonesia bersama Dewan Perwakilan Rakyat Republik Indonesia mengesahkan Undang-Undang Nomor 14 Tahun 2008 tentang Keterbukaan Informasi Publik (selanjutnya disebut UU KIP). Hanya saja, undang-undang dimaksud mulai diberlakukan dua tahun sejak diundangkan ${ }^{3}$.

Secara umum, UU KIP memuat ketentuan tentang hak dan kewajiban publik, hak dan kewajiban badan publik, serta pengaturan terkait Komisi Informasi. Berdasarkan pertimbangan sosiologis dipahami bahwa hak atas informasi publik merupakan hak konstitusional setiap warga negara Indonesia. Dan, setiap badan publik pemerintah dan non pemerintah diwajibkan melaksanakan pemenuhan hak dimaksud melalui penyediaan, pengelolaan serta pelayanan atas informasi publik. Selain itu, badan publik wajib menyediakan informasi publik yang akurat, benar, dan tidak menyesatkan ${ }^{4}$. Dalam melakukan kewajibannya, badan publik harus membangun dan mengembangkan sistem informasi dan dokumentasi untuk mengelola Informasi Publik secara baik dan efisien sehingga dapat diakses dengan mudah ${ }^{5}$.

Lalu, lembaga apasaja yang dapat dinyatakan sebagai badan publik? Jika merujuk UU KIP Pasal 1 angka 3 maka badan publik dimaknai lembaga eksekutif, legislatif, yudikatif, dan badan lainnya yang fungsi dan tugas pokoknya berkaitan dengan penyelenggaraan negara, yang sebagian atau seluruh dananya bersumber dari Anggaran Pendapatan dan Belanja Negara (APBN) dan/atau Anggaran Pendapatan dan Belanja Daerah (APBD), atau organisasi nonpemerintah sepanjang sebagian atau seluruh dananya bersumber dari APBN dan/atau APBD, sumbangan masyarakat, dan/atau luar negeri. Berikutnya, jenis badan publik dapat dipastikan dalam Lampiran I Peraturan Komisi Informasi Nomor 1 Tahun 2010 tentang Standar Layanan Informasi Publik (Perki SLIP). Dengan demikian, Perguruan Tinggi dapat dipastikan sebagai badan publik karena lembaga yang menyelenggarakan pendidikan tinggi, penelitian dan pengabdian kepada masyarakat.

Namun, dalam hal keterbukaan informasi publik, Perguruan Tinggi masih belum optimal dalam pemenuhan hak publik atas informasi publik. Merujuk data KIA per Januari 2017, diketahui bahwa terdapat 5 (lima) Perguruan Tinggi di Aceh telah disengketakan oleh pemohon informasi publik, yaitu Universitas Teuku Umar (UTU),

\footnotetext{
${ }^{2}$ Lihat UUD 1945, Amandemen Kedua, Pasal 28 F.

${ }^{3}$ Lihat UU KIP Pasal 64 ayat (2).

${ }^{4}$ Lihat UU KIP Pasal 7 ayat (2).

${ }^{5}$ Lihat UU KIP Pasal 7 ayat (3).
} 
Community: Volume 4, Nomor 2, Oktober 2018

ISSN: 2477-5746 e-ISSN: 2502-0544

Universitas Syiah Kuala (Unsyiah), UIN Ar-Raniry, Universitas Jabal Ghafur (Unigha), dan STKIP Bina Bangsa Meulaboh.

Pernyataan yang acapkali muncul dari perwakilan badan publik saat pelaksanaan sidang sengketa informasi publik, antara lain :

1. belum mengetahui tentang pelaksanaan UU KIP (padahal sudah berlaku sejak 2010 lalu);

2. badan publik belum membentuk Pejabat Pengelola Informasi dan Dokumentasi (PPID);

3. harus berkoordinasi dengan pimpinan, serta

4. mempertanyakan tentang alasan permohonan informasi yang diajukan oleh Pemohon dan tujuan pemanfaatan informasi yang dimohonkan.

Harus diakui masih adanya pandangan yang berbeda terkait keterbukaan informasi publik di lingkungan Perguruan Tinggi. Secara umum masih terdapat pimpinan Perguruan Tinggi mempertanyakan tentang urgensinya publik (diluar Perguruan Tinggi) untuk mengetahui sejumlah informasi publik di kampus. Perbedaan ini muncul karena kurangnya sosialisasi pada badan publik, terutama Perguruan Tinggi. Selain itu, penyebab lambannya pelaksanaan UU KIP antara lain karena keterbatasan anggaran serta kurangnya desakan publik kepada Perguruan Tinggi untuk melaksanakan UU KIP. Untuk itu, diperlukan upaya bersama agar layanan informasi publik dilingkungan Perguruan Tinggi dilaksanakan sesuai ketentuan yang berlaku.

Sebagaiana uraian di atas, penulis hendak mendalami lebih lanjut mengenai peran Perguruan Tinggi dalam membangun budaya keterbukaan informasi publik. Penelitian ini bertujuan mengetahui kesiapan Perguruan Tinggi dalam melaksanakan UU KIP dan peran yang dapat dilakukan oleh Perguruan Tinggi untuk membangun budaya keterbukaan informasi publik.

\section{TINJAUAN PUSTAKA}

Konsep yang dirujuk dalam penelitian ini terdapat dua bagian, yakni tentang peran dan Perguruan Tinggi, dengan penjelasan sebagai berikut :

\subsection{Peran}

Peran dapat dimaknai suatu rangkaian perilaku yang dilaksanakan oleh seseorang ataupun institusi. Menurut Thoha (2012: 263) bahwa konsep peran dimaknai sebagai satu rangkaian perilaku yang diharapkan oleh seseorang. Istilah peran dipinjam dari panggung teater untuk menjelaskan apa saja yang dapat dimainkan oleh seorang 
artis. Jika merujuk pada sebuah organisasi, ia berkait dengan pemahaman atau perpaduan antara tujuan dan misi organisasi ${ }^{6}$.

Sementara itu, menurut Narwoko (2004:138) peran merupakan aspek yang dinamis dari kedudukan (status). Hal ini bermakna bahwa seseorang telah menjalankan hak-hak dan kewajiban-kewajibannya sesuai dengan kedudukannya, maka orang tersebut telah melaksanakan sesuatu peran ${ }^{7}$.

Selanjutnya, Narwoko (2004) menyatakan bahwa suatu peran paling sedikit meliputi 3 (tiga) hal ${ }^{8}$, yaitu:

1. Peran meliputi norma-norma yang dihubungkan dengan posisi atau tempat seseorang dalam masyarakat;

2. Peran dimaknai suatu konsep ikhwal apa yang dapat dilakukan oleh seseorang dalam masyarakat; dan

3. Peran juga boleh dimaknai sebagai perilaku individu yang penting bagi struktur sosial masyarakat.

Sesuai uraian di atas dapat dipahami bahwa peranan dapat dilakukan secara individu atau seseorang sesuai status sosialnya maupun peranan juga dapat dilakukan oleh lembaga atau instansi tertentu untuk kepentingannya maupun pengembangan masyarakat.

\subsection{Perguruan Tinggi}

Berdasar Undang-Undang Nomor 12 tentang Perguruan Tinggi (UU PT) dinyatakan bahwa Perguruan Tinggi adalah satuan pendidikan yang menyelenggarakan Pendidikan Tinggi ${ }^{9}$. Mengenai Pendidikan Tinggi dinyatakan sebagai jenjang pendidikan setelah pendidikan menengah yang mencakup program diploma, program sarjana, program magister, program doktor, dan program profesi, serta program spesialis, yang diselenggarakan oleh perguruan tinggi berdasarkan kebudayaan bangsa Indonesia ${ }^{10}$.

Selain itu, jika merujuk penjelasan UU PT diketahui bahwa Perguruan Tinggi mempunyai peran penting dan strategis dalam mencerdaskan kehidupan bangsa, dengan mengembangkan ilmu pengetahuan dan teknologi untuk memajukan kesejahteran umum dan keadilan sosial bagi seluruh rakyat Indonesia. Hal ini selaras dengan salah satu tujuan pembentukan UU KIP, yakni Pasal 3 huruf $\mathrm{f}$ yang menyebutkan "mengembangkan ilmu pengetahuan dan mencerdaskan kehidupan bangsa".

\footnotetext{
${ }^{6}$ Miftah Thoha (2012) Perilaku Organisasi: Konsep Dasar dan Aplikasinya. Jakarta: PT. RajaGrafindo Persada. Lihat juga dalam Tesis Afrizal Tjoetra (2017:75-76) Transformasi Organisasi Masyarakat Sivil Dan Kelestarian Perdamaian di Aceh, Indonesia.

${ }^{7}$ J. Dwi Narwoko (2004:138-139). Sosiologi: Teks Pengantar dan Terapan. Jakarta: Prenada Media.

${ }^{8}$ Ibid, halaman 139.

${ }^{9}$ Lihat UU PT Pasal 1 angka 6.

${ }^{10}$ Lihat UU PT Pasal 1 angka 2.
} 
Sebagai badan publik, tentu saja Perguruan Tinggi memiliki hak dan kewajiban dalam pengelolaan informasi publik, termasuk kewajiban membentuk PPID. Pengaturan mengenai PPID dilingkungan Perguruan Tinggi dapat dirujuk pada Peraturan Menteri Riset, Teknologi, Dan Pendidikan Tinggi Republik Indonesia Nomor 75 Tahun 2016 tentang Layanan Informasi Publik Di Lingkungan Kementerian Riset, Teknologi, Dan Pendidikan Tinggi. Kewajiban ini juga menjadi bagian yang tak terpisahkan untuk mewujudkan akuntabilitas Perguruan Tinggi sebagaimana telah diatur dalam UU PT Pasal 78. Akuntabilitas Perguruan Tinggi merupakan bentuk pertanggungjawaban Perguruan Tinggi kepada masyarakat, terdiri atas akuntabilitas akademik dan akuntabilitas non akademik. Wujud pertanggungjawaban dimaksud disusun dalam sebuah laporan tahunan yang dipublikasikan kepada masyarakat.

Padahal, UU KIP menjamin hak publik untuk memperoleh informasi dan memastikan kewajiban badan publik dalam pengelolaan informasi publik. Penggunaan hak atas informasi publik akan mendorong badan publik untuk aktif memenuhi kewajiban memberikan pelayanan informasi publik. Peran ini seharusnya juga dilaksanakan oleh Perguruan Tinggi, utamanya pemenuhan informasi publik pada mahasiswa sebagai agent of change sekaligus social control. Peran generasi muda untuk mengawal perubahan kondisi sosial politik diperlukan dalam mewujudkan negara yang baik dan bersih, serta melaksanakan keterbukaan informasi publik.

\section{METODE PENELITIAN}

Sumber data utama dalam penelitian kualitatif ialah kata-kata, tindakan, dan selebihnya adalah data tambahan seperti dokumen dan lain-lain (lihat Lofland dan Lofland (1984:47) ${ }^{11}$. Berikutnya, Moleong (2011:157) menyatakan bahwa kata-kata dan tindakan orang-orang yang diamati atau diwawancarai merupakan sumber data utama ${ }^{12}$. Selanjutnya, dinyatakan bahwa walaupun sebagai data tambahan atau sumber kedua, sumber diluar kata dan tindakan tidak boleh diabaikan. Bahan tambahan dimaksud berasal dari sumber tertulis dapat dibagi atas sumber buku dan majalah ilmiah, sumber dari arsip, dokumen pribadi, dan dokumen resmi ${ }^{13}$.

Penelitian ini menggunakan metode kualitatif melalui kajian pustaka. Sumber data utama adalah UU KIP, Perki SLIP, UU PT, laporan hasil evaluasi badan publik yang dilakukan oleh Komisi Informasi Pusat dan Komisi Informasi Aceh. Penelitian ini dilakukan sejak Maret - Agustus 2018.

\section{TEMUAN DANPEMBAHASAN}

\footnotetext{
${ }^{11}$ Lihat dalam Lexy J. Moleong, 2011, halaman 157.

${ }^{12} \mathrm{Ibid}$, Moleong, 2011, halaman 157.

${ }^{13}$ Ibid, Moleong, 2011, halaman 159.
} 
Pelaksanaan budaya akademik di Perguruan Tinggi tak dapat dipisahkan dengan pengelolaan informasi publik. Berdasarkan UU KIP, informasi publik dimaknai sebagai informasi yang dihasilkan, disimpan, dikelola, dikirim, dan/atau diterima oleh suatu badan publik yang berkaitan dengan penyelenggara dan penyelenggaraan negara dan/atau penyelenggara dan penyelenggaraan Badan Publik lainnya yang sesuai dengan UU KIP serta informasi lain yang berkaitan dengan kepentingan publik. Informasi publik ini sangat erat kaitannya dengan seluruh rangkaian kegiatan yang berlangsung dalam Perguruan Tinggi, baik dilaksanakan oleh dosen, mahasiswa, serta tenaga non kependidikan. Namun, dalam pelaksanaannya masih memerlukan kerja serius agar pengelolaan informasi publik dapat memenuhi keperluan civitas akademika dan masyarakat secara luas.

Mengapa Perguruan Tinggi harus aktif dalam melaksanakan dan mendorong keterbukaan informasi publik? Setidaknya ada 2 (dua) alasan utama, yaitu pertama, Perguruan Tinggi merupakan badan publik yang tunduk pada UU KIP. Sedangkan kedua, Perguruan Tinggi menjunjung tinggi budaya akademik dalam membina sumber daya manusia yang akan mengisi berbagai struktur sosial dalam masyarakat, pasar dan negara pada masa yang akan datang. Apalagi, dapat dipastikan seluruh agenda Perguruan Tinggi dalam melaksanakan proses belajar mengajar, penelitian, serta pengabdian masyarakat menjadi bagian utama membangun budaya keterbukaan informasi publik dalam masyarakat.

Hanya saja, pelaksanaan UU KIP belum berjalan efektif dalam dunia pendidikan tinggi. Hal ini sebagaimana hasil evaluasi Komisi Informasi Pusat maupun KIA. Pelaksanaan evaluasi badan publik berdasarkan Perki SLIP Pasal 37 ayat (1) dan ayat (2) sebagai berikut:

“(1) Komisi Informasi dapat melakukan evaluasi pelaksanaan layanan informasi publik oleh badan publik 1 (satu) kali dalam setahun. (2) Hasil evaluasi sebagaimana dimaksud pada ayat (1) disampaikan kepada Badan Publik dan diumumkan kepada publik".

Sedangkan penetapan hasil akhir peringkat kualifikasi badan publik dilakukan dengan merujuk Pasal 8 pada Perki 5 Tahun 2016 tentang Metode dan Teknik Evaluasi Keterbukaan Informasi Badan Publik, yang terdiri atas:

a. Informatif dengan nilai $97-100$;

b. Menuju informatif dengan nilai $80-96$;

c. Cukup informatif dengan nilai $60-79$;

d. Kurang informatif dengan nilai $40-59$; dan

e. Tidak informatif dengan nilai $<39$. 
Community: Volume 4, Nomor 2, Oktober 2018

ISSN: 2477-5746 e-ISSN: 2502-0544

Berdasarkan hasil evaluasi Komisi Informasi Pusat rata-rata keterbukaan informasi pada 85 badan publik Perguruan Tinggi Negeri berada pada kualifikasi cukup informatif (dengan nilai 73,31), dengan rincian sebagai berikut ${ }^{14}$ :

\begin{tabular}{|c|l|l|c|c|c|}
\hline No. & Peringkat & \multicolumn{1}{|c|}{ Perguruan Tinggi } & Kualisifikasi & Nilai & Ket. \\
\hline 1. & Peringkat I & Universitas Brawijaya & Informatif & 97.23 & \\
\hline 2. & Peringkat II & Universitas Indonesia & Menuju Informatif & 96.04 & \\
\hline 3. & Peringkat III & Institut Pertanian Bogor & Menuju Informatif & 82.71 & \\
\hline 4. & Peringkat IV & Universitas Negeri Malang & Cukup Informatif & 78.25 & \\
\hline 5. & Peringkat V & Universitas Padjajaran & Cukup Informatif & 76.12 & \\
\hline 6. & Peringkat VI & Universitas Gadjah Mada & Cukup Informatif & 70.41 & \\
\hline 7. & Peringkat VII & Universitas Lambung Mangkurat & Cukup Informatif & 62.4 & \\
\hline 8. & Peringkat VIII & Universitas Negeri Yogyakarta & Cukup Informatif & 60.5 & \\
\hline 9. & Peringkat IX & Institut Teknologi Bandung & Kurang Informatif & 56.94 & \\
\hline 10. & Peringkat X & Universitas Sriwijaya & Kurang Informatif & 52.51 & \\
\hline
\end{tabular}

Berikutnya, hasil evaluasi KIA pada 2017 lalu, diketahui bahwa secara umum Perguruan Tinggi Negeri (PTN) di Aceh termasuk kualifikasi tidak informatif, dengan gambaran sebagai berikut ${ }^{15}$ :

\begin{tabular}{|c|c|c|c|}
\hline No & $\begin{array}{c}\text { Jumlah BP } \\
\text { Evaluasi }\end{array}$ & Kualifikasi Peringkat & $\begin{array}{c}\text { BP } \\
\text { (Hasil ) }\end{array}$ \\
\hline 1. & \multirow{5}{*}{12 BP PTN } & Informatif dengan nilai $97-100$; & 0 \\
\hline 2. & & Menuju informatif dengan nilai $80-96$ & 0 \\
\hline 3. & & Cukup informatif dengan nilai $60-79$; & 1 \\
\hline 4. & & Kurang informatif dengan nilai $40-59$; & 0 \\
\hline 5. & & Tidak informatif dengan nilai $<39$ & 11 \\
\hline
\end{tabular}

Berikutnya, hasil peringkat 5 (lima) besar PTN di Aceh untuk tahun $2017^{16}$ adalah :

\footnotetext{
${ }^{14}$ Lihat www.komisiinformasi.go.id Laporan Evaluasi Badan Publik oleh Komisi Informasi Pusat, 2017, diakses pada 3 April 2018.

${ }^{15}$ Laporan Evaluasi Badan Publik di Aceh Tahun 2017, Komisi Informasi Aceh.

${ }^{16}$ Ibid.
} 


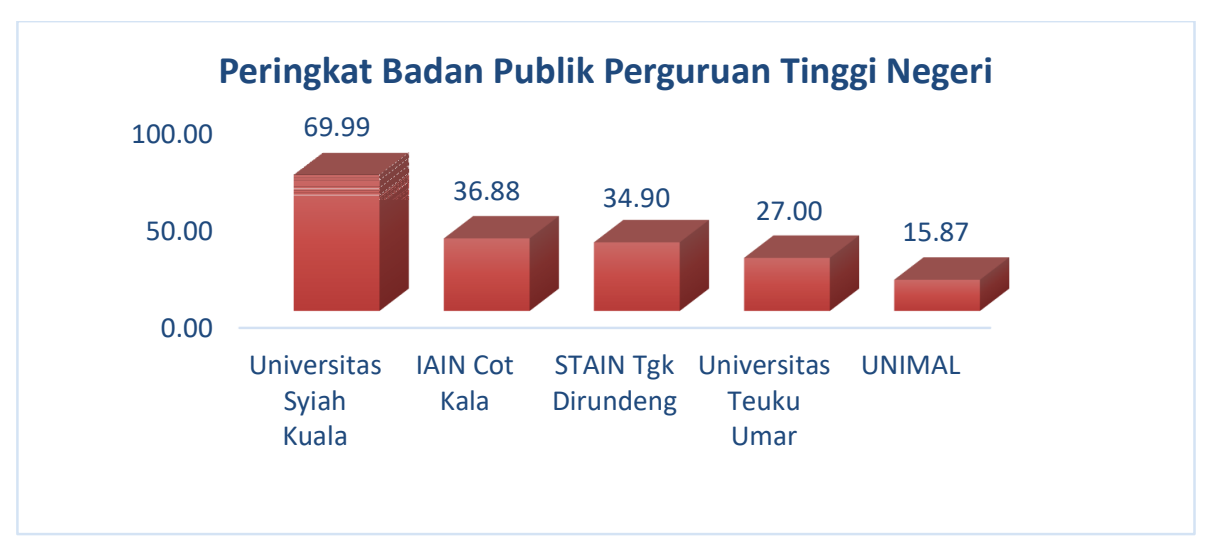

Berdasarkan hasil evaluasi di atas, diketahui bahwa PTN di Aceh masih kurang dalam melaksanakan ketentuan UU KIP. Pengelolaan informasi publik seharusnya menjadi bagian yang tak terpisahkan dalam pengembangan sumber daya manusia.

Apalagi proses interaksi dalam lingkungan Perguruan Tinggi sangat erat kaitannya dengan pengelolaan dan pemanfaatan informasi publik. Keperluan atas informasi publik di Perguruan Tinggi ibarat "ikan memerlukan air untuk melangsungkan kehidupannya". Keperluan atas informasi publik sangat mendukung keperluan dosen dan/atau mahasiswa melaksanakan Tridharma Perguruan Tinggi, baik informasi publik bersumber dari internal kampus maupun badan publik lainnya.

Berdasarkan konsep peran serta keberadaan Perguruan Tinggi untuk membangun budaya keterbukaan informasi di atas, maka sangat dimungkinan Perguruan Tinggi melaksanakan sejumlah peran sebagai berikut :

1. Sebagai "lokomotif" dalam melaksanakan UU KIP dengan pembenahan sistem pengelolaan informasi secara benar, akurat, dan mudah diakses;

2. Sebagai "fasilitator" dalam membangun masyarakat sadar informasi, yang memanfaatkan informasi publik untuk meningkatkan partisipasi aktif masyarakat dalam pengambilan kebijakan publik dan pengelolaan badan publik yang baik; dan

3. Sebagai "motivator" agar masyarakat dan badan publik lainnya dapat memanfaatkan penyediaan informasi publik untuk pengembangan ilmu pengetahuan dan mencerdaskan kehidupan bangsa.

\section{KESIMPULAN}

Sesuai dengan paparan di atas, penulis menyampaikan kesimpulan mengenai kesiapan dan peran Perguruan Tinggi dalam pelaksanaan UU KIP sebagai berikut :

1. Kesiapan Perguruan Tinggi dalam melaksanakan UU KIP belum optimal. Masih terdapat sejumlah tantangan yang harus dikelola bersama secara internal maupun dukungan komponen lainnya. Tantangan dimaksud antara lain :

a. Memastikan setiap informasi publik dapat diakses oleh civitas akademika dan masyarakat sesuai dengan ketentuan UU PT. Selain itu, sebagai badan publik 
maka Perguruan Tinggi harus melaksanakan UU KIP sebagaimana yang telah ditetapkan, termasuk Perki SLIP dan Perki Nomor 1 Tahun 2013 tentang Prosedur Penyelesaian Sengketa Informasi Publik.

b. Memastikan pembangunan budaya akademik secara terbuka di kampus melalui pengelolaan informasi publik dan pelayanannya untuk mendukung penciptaan lingkungan Perguruan Tinggi yang terbuka dan meningkatkan sikap saling menghargai atas karya ilmiah yang dihasilkan seseorang.

2. Peran yang dapat dilakukan Perguruan Tinggi untuk membangun budaya keterbukaan informasi publik dapat dilaksanakan melalui 3 hal, yaitu sebagai "lokomotif" dalam melaksanakan UU KIP; sebagai "fasilitator" dalam membangun masyarakat sadar informasi; dan sebagai "motivator" agar masyarakat dan badan publik lainnya dapat memanfaatkan penyediaan informasi publik untuk pengembangan ilmu pengetahuan dan mencerdaskan kehdupan bangsa.

Sedangkan sejumlah saran yang dapat penulis sampaikan untuk optimalisasi kesiapan dan peran PT dalam pelaksanaan UU KIP sebagai berikut :

1. Perguruan Tinggi agar dapat meningkatkan fungsi dan layanan PPID sebagai bagian utama dalam membangun budaya akademik di kampus. Khusus Perguruan Tinggi di Aceh diharapkan menjadi pelopor dalam transformasi budaya masyarakat Aceh pasca konflik melalui pembentukan generasi penerus sebagai agen perubahan dan kontrol sosial. Meningkatkan kesadaran masyarakat atas pentingnya informasi publik; utamanya pemanfaatan informasi publik untuk meningkatkan partisipasi aktifnya dalam pembangunan.

2. Masyarakat serta komponen organisasi masyarakat sipil untuk membangun sinergi dengan lembaga-lembaga publik. Hal ini berkaitan erat dengan pengelolaan informasi publik dan kepentingan Perguruan Tinggi atas sejumlah informasi untuk mendukung tri dharmanya. Sehingga, berbagai upaya yang berlangsung secara khusus dapat mendorong kualitas partisipasi aktif masyarakat dalam pembangunan perdamaian di Aceh.

\section{DAFTAR PUSTAKA}

\section{Buku}

J. Dwi Narwoko (2004). Sosiologi: Teks Pengantar \& Terapan. Jakarta: Prenada Media.

Miftah Thoha (2012). Perilaku Organisasi: Konsep Dasar dan Aplikasinya. Jakarta: PT. RajaGrafindo Persada. 
Community: Volume 4, Nomor 2, Oktober 2018

ISSN: 2477-5746 e-ISSN: 2502-0544

Moleong, Lexy J., (2011) Metodologi Penelitian Kualitatif, Edisi Revisi. Bandung: PT Remaja Rosdakary.

\section{$\underline{\text { Website }}$}

Laporan Evaluasi Badan Publik oleh Komisi Informasi Pusat, 2017, diakses 3 April 2018 pada www.komisiinformasi.go.id.

\section{$\underline{\text { Laporan Penelitian/Tesis }}$}

Afrizal Tjoetra. 2017. “Transformasi Organisasi Masyarakat Sivil Dan Kelestarian Perdamaian di Aceh, Indonesia". Malaysia: Universiti Sains Malaysia (USM).

Laporan Perkembangan Penyelesaian Sengketa Informasi Publik, Komisi Informasi Aceh, 2017.

Laporan Evaluasi Badan Publik, Komisi Informasi Pusat, 2017.

Laporan Evaluasi Badan Publik, Komisi Informasi Aceh, 2017.

\section{Peraturan Perundang-undangan}

Undang-Undang Dasar 1945.

Undang Undang Nomor 14 Tahun 2008 tentang Keterbukaan Informasi Publik.

Undang Undang Nomor 12 Tahun 2012 tentang Perguruan Tinggi.

Peraturan Komisi Informasi Nomor 1 Tahun 2010 tentang Standar Layanan Informasi Publik.

Peraturan Komisi Informasi Nomor 1 Tahun 2013 tentang Prosedur Penyelesaian Sengketa Informasi Publik.

Peraturan Komisi Informasi Nomor 5 Tahun 2016 tentang Metode dan Teknik Evaluasi Keterbukaan Informasi Badan Publik.

Peraturan Menteri Riset, Teknologi, Dan Pendidikan Tinggi Republik Indonesia Nomor 75 Tahun 2016 tentang Layanan Informasi Publik Di Lingkungan Kementerian Riset, Teknologi, Dan Pendidikan Tinggi. 